THE ILLUSION OF GIVIL SOGIETY 


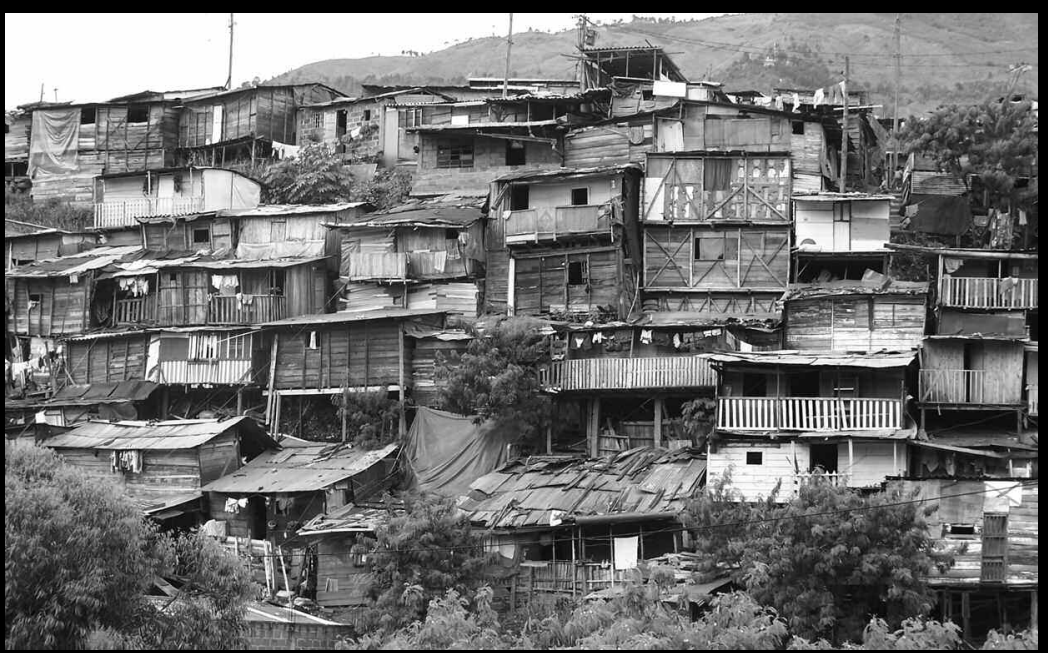




\section{JON SHEFNER}

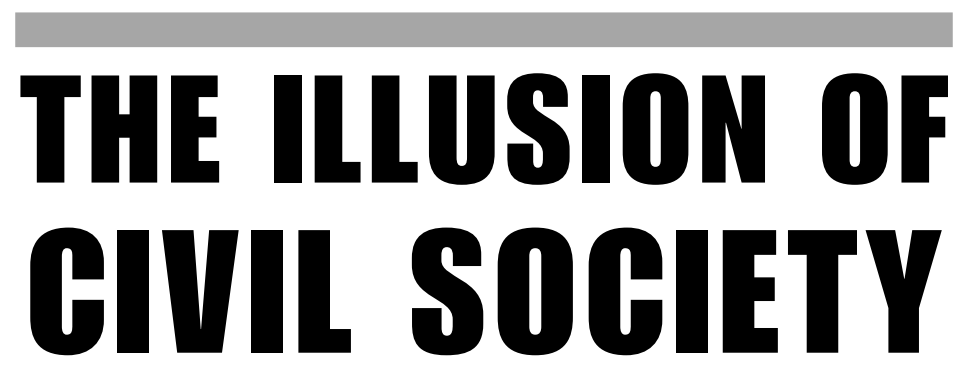

\section{DEMOCRATIZATION AND GOMMUNITY MOBILIZATION IN LOW-INCOME MEXICO}

THE PENNSYLVANIA StaTE UNIVERSITY PRESS

UNIVERSITY PARK, PENNSYLVANIA 
LIBRARY OF CONGRESS

CATALOGING-IN-PUBLICATION DATA

Shefner, Jon, 1958

The illusion of civil society : democratization and community mobilization in low-income Mexico / Jon Shefner.

p.

$\mathrm{cm}$.

Includes bibliographical references and index.

Summary: "Addresses the success and failures of the Unión de Colonos Independientes (UCI), a community organization in Guadalajara, Mexico. Critiques the civil society concept and questions the strategy of political democratization as a way to assert control over the global economy"-Provided by publisher.

ISBN 978-0-271-03384-6 (cloth : alk. paper)

1. Unión de Colonos Independientes (Guadalajara, Mexico).

2. Community organization-Mexico-Guadalajara.

3. Civil society-Mexico-Guadalajara.

4. Democratization-Mexico-Guadalajara.

I. Title.

HN120.G8S48 2008

$320.972 ' 35-\mathrm{dc} 22$

2008016408

Copyright $(9) 2008$

The Pennsylvania State University

All rights reserved

Printed in the United States of America

Published by

The Pennsylvania State University Press

University Park, PA 16802-1003

The Pennsylvania State University Press is a member of the Association of American University Presses.

It is the policy of The Pennsylvania State

University Press to use acid-free paper.

This book is printed on Natures Natural, containing $50 \%$ post-consumer waste, and meets the minimum requirements of American National Standard for Information Sciences-Permanence of Paper for Printed Library Material, ANsI Z39.48-1992. 
THIS BOOK IS DEDICATED TO THE UCI, FOR ALL THEY TAUGHT ME. And to Karen, for everything. 
